\title{
Interpersonal Function Analysis of Discourse from the Perspective of Critical Discourse Analysis
}

\author{
—Take Trump's Victory Speech in 2016 Henan University of Technology \\ Fan Menghe, Bao Chenglian
}

\begin{abstract}
Keywords: Critical discourse analysis; Interpersonal function; Three dimensional framework; Donald Trump
\end{abstract}

\begin{abstract}
Fairclough's three-dimensional analysis model of critical discourse analysis with Halliday's interpersonal function in the system functional grammar. Taking the speech of Trump's election as an example, this paper reveals the differences between Western political discourse the relationship between language, power and ideology and the meaning of interpersonal function contained in the speech, and hopes to provide readers with a critical thinking to read Chinese and foreign political discourse.
\end{abstract}

\section{Introduction}

As the process of globalization has accelerated, diplomatic activities to enhance bilateral cooperation and understanding have been more widely used in political discourse. At present, many scholars began to use critical thinking to analyze the political discourse, not only to investigate the written form of language, oral form of political discourse has been caught the attention of people, such as through comparison and analysis of the political discourse of China and the United States, to reveal the language differences and their causes of political discourse in China and the United States, which lead to different ideologies behind the two countries. Although the political discourse is subject to the subjective influence of the speaker, it is also the ideological or power status of the speaker that plays a decisive role in political discourse. This paper selects the Trump's victory speech as the research object, the speech by Fairclough's three-dimensional critical discourse analysis model and interpersonal function of Halliday's systemic functional grammar theory as the instruction, from the perspective of critical discourse analysis to interpret the Trump's victory speech, aimed at readers with critical thinking reading Chinese and foreign political discourse.

\section{Theoretical framework and research methods}

Halliday's systemic functional grammar framework can be used to reveal the deep meaning of discourse, and to understand and interpret the text of the semantic and stylistic features, this is not only very important to interpret and appreciate the text, but also has practical application value for the English reading comprehension teaching. (Fang Yan, 2005:5)

"If we don't have knowledge of the language system, we can't explain how the text is expressed, or the value and effectiveness of the discourse. Similarly, if we don't understand the meaning of discourse expressed (including specific language form expressed by the peculiar meaning), it will not be able to observe language system through communicative activities in the discourse, also can't see a single language phenomenon and as a system of language." Huang Guowen noted.

Therefore, systematic functional grammar and critical discourse analysis complement each other and benefit each other. A discourse based on social practice, Fairclough proposed about critical discourse analysis of the "three dimensional analysis model", including the textual description, interpretation, and explanation. " He added, Description refers to the formal structure characteristics of the descriptive text; Interpretation refers to the relationship between the formation and dissemination of the discourse, the communication and acceptance of its communicative process; Explanation is to explain the relationship between the communicative process and its social context. In this model, three characteristics of vocabulary, lexical and textual structures are analyzed. The 
relationship between discourse and the generative process of discourse is focused on the interpretation level. Explanation level pay more attention to the relationship between discourse and power and struggle. (Fairclough, 1992:43) From the foregoing, the natural language of the vocabulary and grammar system necessarily implies social significance, but this kind of social significance displays recessive characteristics, people may draw a vocabulary, grammar, social significance through the critical discourse analysis.

In addition, Halliday believes that the use of language has three major functions: to convey the conceptual function of the speaker's inner world and the outer world, to reflect the interpersonal functions that reveal the relationships among people, and to organize the languages into contexts article features. Critical discourse analysis holds that "language is an integral part of the social process." Interpersonal function refers to the ability of the author (speaker) to express the author's (speaker's) identity, status, attitude, motivation and extrapolation of things (Zeng Yaping, 2009). Modality is a kind of interpersonal performance, that is to say, modality system is an important part of interpersonal function, which is the speaker's judgment on the success and effectiveness of the proposition he speaks. In English, apart from modal verbs, modal adjectives and modal adverbs, personal pronouns, real verbs, direct and indirect quotations can express modal meaning. Except the three-dimensional analysis model, this paper also discusses the use of modal and personal pronouns in this speech.

\section{Critical discourse analysis of Trump's speech}

On November 9, 2016, republican presidential candidate Donald Trump delivered a victory speech after winning the election. The speech is a political discourse, with political ideology behind it. Discourse analysis aims to systematically explore the relationship between discourse practice, events, texts and social and cultural structures, relationships, and causal and fuzzy decision process, studies how these practices, events, and the text is produced from the power relations and power struggles and reflected the ideology, to explore how the fuzzy relationship between discourse and social maintaining power and hegemony. (Fairclough, 1995) Therefore, the study of Chinese and western political discourse is of great practical significance for in-depth understanding of leaders and political parties.

Next I will analyze Trump's victory speech from the three-dimensional analysis model (which includes description of discourse, interpretation of discourse, explanation of discourse) and interpersonal function (mainly from the modal verbs and personal pronouns in two aspects).

(1) One of the important ways to realize the conceptual function of the transmission text is the transmission of text. Halliday believes that transference refers to the way in which a sentence reflects its meaning, and how to interpret what happens outside of them or the state of mind. Transference is the bridge between language and the world. It consists of material process, psychological process and behavioral process.

Example 1: I congratulated her and her family on a very, very hard-fought campaign.

actor material process goal

Example 2: We owe her a major debt of gratitude for her service to our country. actor material process goal

Mr Trump has told the audience who will do what is specific and what has happened. Through these two words, Trump conveyed to people his gratitude to Hillary for her contribution to the nation, and he would lead the American people on a new journey.

(2) Passivization in political discourse, politicians prefer to use passive sentences for special political purposes. Different sentence structure and word order can express different meanings. For example, "These are spectacular people, sometimes under appreciated unfortunately, we appreciate them." The subject of the passive sentence is the message that the speaker most wants to convey to the audience. The form of the passive sentence can successfully highlight the key of information that the speaker wants to express.

(3) The use of nominalization makes it difficult for the audience to identify the temporal 
selection in the speaker's discourse, to weaken the participants in the event, and to highlight the message that the speaker wants to convey, which is also in line with the political discourse to convey the main characteristics of the message.

Example 1: Now it is time for America to bind the wounds of division.

Example 2: We will embark upon a project of national growth and renewal.

(1) The choice of personal pronoun is in the discourse, we, you, our, etc and other personal pronouns frequently appear, representing a wide range of social and political positions. Politicians use personal pronouns that contain sexual characteristics to bring them closer to the audience, and to empathize with the audience.

Example 1: We're going to rebuild our infrastructure, ....and we will put millions of our people to work as we re-build it.

Example 2: I look very much forward to being your president and hopefully at the end of two years ... you will say so many of you worked so hard for us.

In example 2, the speaker used a word "you" can attract the attention of the audience, and to highlight his status as a national leader in this society, increased the authority of speech, obtained audience's trust, achieve the political purpose of the speaker.

(2) there is unmarked theme and the marked theme. The unmarked theme indicating the position of the subject in the main position.

Example 1: I mean she fought very hard.

Example 2: We are going to fix our inner cities and rebuild our highways, bridges, tunnels, airports, schools, hospitals.

Mr Trump, who inspires his supporters in the form of unmarked theme to achieve political ends, clearly demonstrates his point of view, echoing the theme of the whole discourse. The marked theme refer to a sentence other than the subject appears in the main position. The role of marking theme includes: indicating time, reflecting attitude of the speaker, etc.

Example 3: I say it is time for us to come together as one united people.

Example 4: That is now what I want to do for our country.

(1) Social context. Mr. Fairclough noted that social context can mediate the relationship between the discourse and social structure. Only by explaining the discourse in terms of social context can we obtain the deep information behind the text and discuss the relationship between discourse and power and the struggle process. (1)Political background. The polarization of parties and the rise of interest groups have caused a great shock to American democracy and the public interest has been difficult to be promoted and maintained, which has plunged us politics into chaos. (2)Economic background. The global economy is slowing, baby boomers are entering retirement age and other factors that make the U.S. economy unsatisfactory. (3) The diplomatic background. The anti-terrorism situation is still serious; American and Russian conflicts in Europe need multilateral consultation; Detente with some third world countries such as China and Russia. Under the influence of the above social context, Trump's speech will inevitably instill the current social context.

Example 1: We have a great economic plan. We will double our growth and have the strongest economy anywhere in the world.

Example 2: I want to tell the world community that while we will always put America's interests first, we will deal fairly with everyone, with everyone. All people and all other nations. We will seek common ground, not hostility, partnership, not conflict.

(2) Language and ideology. Traditional linguists believe that language is not only communication in society, it is more a social practice. Language consists in society, not in isolation. Only by putting the language in the social context, can we accurately infer the ideology behind the language.

In the above analysis of Trump's speech, the author reveals some of the ideology hidden behind the text, and expresses it through Trump's clever choice of language in his speech. People will be more or less affected by this hidden ideology, thereby making its own judgment on whether the 
incoming Trump administration can revitalize the United States. To sum up, the ideology behind the study is more important than the pure research language itself.

Modality refers to the speaker's opinion or attitude toward the true value of the proposition in the sentence because the speaker asks the other party to take an obligation in the order or to express his / her own will in the proposal (Hu, 2005). The use of modal words can make their own claims without mandatory colors, making the information easier for the audience to accept, thereby increasing the chance that the information will be recognized by the audience. The use of modal verbs often reflects the attitudes, opinions and wishes of the speakers. The modal values of different modal verbs are also different. Halliday divides modal verbs into high, medium and low grades, which reflects the severity of the speaker's tone. High value are: must, ought to, need and have to. The median values are: will, would, shall and should. Low values include: may, might, can and could. Different modal verbs can express different modal meanings and show the speaker's role orientation. The following is Halliday's division of modal verbs

Table 1 The value of modal verbs

\begin{tabular}{|c|c|c|c|}
\hline & Low value & Median value & High value \\
\hline positive & $\begin{array}{l}\text { can, may, could, } \\
\text { might, (dare) }\end{array}$ & $\begin{array}{l}\text { will, would, } \\
\text { should, is/was to }\end{array}$ & $\begin{array}{l}\text { must, ought to, } \\
\text { need, has/had to }\end{array}$ \\
\hline negative & $\begin{array}{c}\text { needn't, } \\
\text { doesn't/didn't, } \\
\text { need to, have to }\end{array}$ & $\begin{array}{l}\text { won't, wouldn't, } \\
\text { shouldn't, } \\
\text { (isn't/wasn't to) }\end{array}$ & $\begin{array}{l}\text { mustn't, oughtn't } \\
\text { to, can't, couldn't, } \\
\text { (mayn't, mightn't, } \\
\text { hasn't/hadn't to) }\end{array}$ \\
\hline
\end{tabular}

In his speech, Trump has a total of 1,647 words and 44 modal verbs, accounting for $2.7 \%$ of the full-text vocabulary, of which "will" and "can" are the most frequent. The most widely used in Trump's winning speech is the middle value modal verb (32), followed by the low value modal verb (7), which together account for $89 \%$ of full-text modal verbs.

In this speech, Trump also used the high value modal verb "must" 1 times and "have to" 4 times. The use of high-value modal verbs can demonstrate that Trump possesses the authority and appeal of the U.S. president and expresses a mandatory attitude. Trump's use of such modal verbs in this speech shows his subjective orientation, emphasizing the need to rebuild our nation, reshape the American dream and make the United States the most powerful economy in the world, while also emphasizing that with other countries to establish friendly relations and to unite and unite the United States can make the United States more prosperous and powerful.

Among the moderate verbs, "will" is the most frequently used in this speech, with a total of 29 appearances. Other appearances like "would" appear twice and "should" appeared once. Trump's use of "will" at high frequencies has eased his mood and made it more convincing. One is to express his gratitude and to express his gratitude to everyone who has worked hard for his election. Second, he uses "will" to illustrate Trump's determination that as he becomes the president of the United States, he will work hard for civil rights equality, for the future development of the United States, for the realization of the American dream and struggle.

The last low-value modal verb "can" appeared seven times. Such words make the tone of speech soft, there is a kind of consultation tone doping which narrowed the distance between Trump and people, so that people feel the affinity of the president of the United States.

The use of these modal verbs has made Trump's sense of distance from people, creating an emotional resonance that reaches ideological control and at the same time establishes the unshakable image of the U.S. leaders.

In discourse, pronouns refer to how the author can tell us the characters involved in the discourse, and these personal pronouns help to establish a particular relationship between the author and the reader. In many languages, the choice of personal pronouns is often limited by the social status, power relationship, and degree of familiarity of the communicators (Zhang and Lin, 2012). Personal 
pronouns can achieve the interpersonal meaning of discourse, the choice of personal pronouns often change due to speaking, listening to both the status and degree of change. Statements made by politicians often impose their will on the audience in such a way. Personal conversions are characteristic of this speech, and different people play different roles in sentences. The next section focuses on the use of personal pronouns in interpersonal functions in Trump's presentations.

Table 2 The use of personal pronouns in Trump's presentations

\begin{tabular}{|c|c|c|c|c|c|}
\hline & Person & Frequency & Rate(\%) & Total & Rate of total(\%) \\
\hline \multirow{6}{*}{$\begin{array}{l}\text { First } \\
\text { person }\end{array}$} & we & 45 & 29.4 & \multirow{6}{*}{153} & \multirow{6}{*}{68.3} \\
\hline & our & 33 & 21.6 & & \\
\hline & $\mathrm{I}$ & 39 & 25.5 & & \\
\hline & me & 19 & 12.4 & & \\
\hline & my & 12 & 7.8 & & \\
\hline & us & 6 & 3.9 & & \\
\hline \multirow{2}{*}{$\begin{array}{l}\text { second } \\
\text { person }\end{array}$} & you & 43 & 91.5 & \multirow[t]{2}{*}{46} & \multirow[t]{2}{*}{21} \\
\hline & your & 4 & 8.5 & & \\
\hline \multirow{3}{*}{$\begin{array}{l}\text { Third } \\
\text { person }\end{array}$} & they & 17 & 70.8 & \multirow[t]{3}{*}{24} & \multirow[t]{3}{*}{10.7} \\
\hline & their & 2 & 8.3 & & \\
\hline & them & 5 & 20.8 & & \\
\hline
\end{tabular}

The following focuses on the analysis of several high-frequency use of personal pronouns in speeches in the use of the situation.

In their speeches, politicians are very good at using the first person to adjust the psychology distance with the audience so as to make the speech more contagious and convincing so as to achieve the goal of controlling the audience (Huang Yinju, 2011). In this speech, "we" is the most frequently used, referring to all U.S. citizens, including Trump. In his speech, Trump made extensive use of "we" as a subject to create a friendly atmosphere that narrowed his distance from the audience and made the content of his speech more acceptable to form the starting point for speakers and listeners and the same feeling of position. In addition, Trump uses "our" to highlight a shared feeling that everyone has a country that is common to all of us and requires us to work together to build it.

In this speech, the second person pronoun "you" is also frequently used, where "you" refers to everyone, Trump would like to thank every American citizen. It also plays a role of wake-up audience ear and makes everyone feel the will and determination of the president to express himself as if he is in face-to-face dialogue with the president so that everyone will feel more cordial and close to the president. The third person pronouns appear relatively low probability, Trump's choice of different personal pronouns, not only reflects his standing on the same position with the audience, but also reflect his majesty as president.

\section{Conclusion}

This article uses the method of critical discourse analysis, combined with the three-dimensional analysis mode proposed by Fairclough, makes a critical discourse on Trump's election speech from three aspects of discourse description, discourse explanation and discourse explanation analyzes and briefly summarizes the characteristics of the political discourse, reveals the relationship between discourse and ideology, aims to provide readers with critical thinking to interpret Chinese and foreign political discourse, but also from the modality of interpersonal function system analysis of special strategy of using modal verbs and personal pronouns in the language of Trump, makes the whole speech fall into the heart of every listener in a loud way and achieve the effect of transmitting information efficiently. In a word, this kind of analysis helps us to improve the appreciation of language ability to better respond to today's language in a variety of social activities. 


\section{References}

[1] Dai Weihua. Discourse Analysis: Review and Outlook [J]. Foreign Language Studies, 1999 (4).

[2] Fairclough, N. Critical Discourse Analysis: The Critical Study of Language[M]. London/ New York: Longman,1995.

[3] Fairclough, N. Discourse and Social Change[M]. Cambridge: Polity Press, 1992.

[4] Fang Yan. System Function Grammar and Discourse Analysis [J] Foreign Language Teaching, 2005 (6).

[5] Huang Guowen. Text analysis and the construction of system functional linguistics theory [J]. Foreign Language and Foreign Languages Teaching,2010 (5).

[6] Hu Zhuanglin. System Functional Linguistics Introduction [M]. Beijing: Peking University Press, 2005.

[7] Huang Yinju. Critical Discourse Analysis of Obama's Beijing Speech [J]. Journal of Harbin Institute of Technology, 2011 (5). 